\title{
EL HOMBRE Y EL AGUA \\ EN LA OBRA DE AUGUSTO ROA BASTOS
}

En las primeras páginas de Hijo de hombre, el viejo Macario, profeta y memoria viviente de Itapé, se dirige a los niños del pueblo en una de sus vacilantes parábolas en las que mezcla la historia y el mito, y les dice: «El hombre, mis hijos, es como un río. Tiene barranca y orilla. Nace y desemboca en otros ríos: alguna utilidad debe prestar. Mal río el que muere en un estero.» Este aforismo es en cierto modo el principio y clave de la novela. Marca la significación del destino paralelo de los dos protagonistas del relato: el de Cristóbal Jara, río que nace y desemboca en otros ríos; el de Miguel Vera, quizá mal río que se muere en un estero. El objeto del presente estudio es ver precisamente en qué medida y en qué forma el río (y el estero), como mediatización de los personajes y de su acción, se constituye en uno de los núcleos generadores de la narrativa de Augusto Roa Bastos.

\section{OBjeto Y METODOLOGÍA}

\subsection{El referente paraguayo}

Hablar del hombre y el río en la obra de un escritor paraguayo es hablar de una evidencia, casi una tautología. Como lo sería hablar del indio y la sierra en la literatura peruana, o del hombre y la ciudad en los escritores de Buenos Aires. En la obra literaria, la sierra, o la gran ciudad, o el río, remiten a un contexto natural, a un mundo percibido, imaginado y representado al que se refieren necesariamente el emisor y el receptor peruanos, porteños o paraguayos. En este caso, lo que nos interesa más particularmente en la obra de Augusto Roa Bastos es el referente paraguayo.

Cuando en su Oda a las Américas Pablo Neruda evoca el Paraguay bajo la sucinta imagen de «turquesa fluvial»; todo está dicho. Para el 
Paraguay, el río tiene una función referencial ineludible si se considera que este pequeño país dispone de una red hidrográfica que es una de las más densas del mundo. El propio nombre del país es el de un río, el Paraguay, río epónimo, como ocurre también con la Argentina y el Uruguay, que constituyen con el Paraguay lo que se ha convenido en llamar la cuenca del Río de la Plata. La vida histórica del Paraguay viene sellada desde los orígenes por el signo del río. Río natural de los guaraníes. Río fatal del descubrimiento y de la conquista por los españoles. Río político de la Colonia y de la Independencia. Río «económico» por fin, en la actualidad, sobre el que se ciernen los intereses de los imperialismos y multinacionales en torno a la represa paraguayo-brasileña de Itaipú y al proyecto paraguayo-argentino de Yaceretá.

\subsection{Inscripción en la obra}

Enraizados en el país de los ríos, y refiriéndose constantemente a él, los relatos de Augusto Roa Bastos son espacios textuales en los que el agua familiar está siempre presente. Agua ubicua, salvo en algunos cuentos de El baldio, que son, y es notable, cuentos del exilio en Buenos Aires, la inmensa ciudad de espaldas al río. En los demás textos, bajo sus formas múltiples y cambiantes, siempre surge el agua, a veces episódica y fugaz, a veces constituyendo el núcleo generador del relato, como en los casos de Carpincheros, El karuguá, El trueno entre las hojas, gran parte de Hijo de hombre y, en alguna medida, como veremos, de Yo el Supremo.

\subsection{Tipología de las formas del agua}

En la obra de Augusto Roa Bastos, el agua y el río raras veces se dan en su forma directamente referencial de emblema o alegoría nacionales. Por su naturaleza misma, el agua es movediza y multiforme. Sin embargo, en cuanto se esboza una tipología de las formas del agua inscritas en el corpus narrativo, se nota rápidamente que todas estas formas múltiples se constituyen en dos grandes conjuntos. Por una parte, están las formas del agua libre que son el río, el arroyo o el manantial. Por otra, están las formas del agua prisionera que son el estero, el bañado, el pantano o la zanja de aguas muertas. Habría que añadir a estas formas constantes del agua otras formas más excepcionales y menos estables como el diluvio, el ciclón, la gran inundación o, por antítesis, la gran sequía.

A esta tipología de las formas del agua corresponde, en grandes 
líneas, una tipología de los personajes que se definen, en parte o en la totalidad, por su relación con el agua. Son los terrícolas, para quienes el agua es tan sólo una presencia episódica o lejana; son los ribereños que comparten su vida con el agua; son los navegantes, para quienes el agua es consustancial. Pero cualquiera que sea su conformidad con el agua, ésta es para muchos de ellos el fin último: es su muerte y es su tumba. Entonces, el agua deja de ser un paisaje para convertirse en un destino casi siempre fatal.

\subsection{Ficción e imaginación material}

Lo que se acaba de decir sobre el referente paraguayo y su función en el destino de los personajes no debe dar lugar a malentendido. La omnipresencia del agua no fundamenta de ningún modo una especie de «realismo», cuya finalidad sería la "veracidad», el «testimonio» o la exaltación de un nacionalismo, o de su anverso, que sería el exotismo. Elemento predominante de un contexto considerado como real, el agua, al inscribirse en el relato, pasa por el filtro de la impulsión creadora del autor, que opera con sus elecciones y sus obsesiones, sus imágenes predilectas o sus cualidades de escritura. En última instancia, el agua representada en el texto no tiene más realidad que la que le conceden las palabras y el discurso que la informan en la ficción.

Escribir sobre el agua es, ante todo, como dice Gaston Bachelard ${ }^{1}$, verbalizar un sueño o un fantasma: «Al cantar los elementos (en este caso el agua) se cree ser fiel a una imagen predilecta, cuando en realidad se es fiel a un sentimiento humano primitivo, a una realidad orgánica primera, a un temperamento onírico fundamental» (p. 7). En este nivel, de realidad y de ficción a la vez, el agua elemental pertenece a lo que Bachelard llama la imaginación material. En literatura, el agua es ficción antes de ser realidad. Las aguas tienen que inscribirse primero en la ficción del texto (la narrativa de Augusto Roa Bastos) para que se pueda hablar después del referente (el Paraguay y las aguas paraguayas). Este mismo principio es el que define una vez más y muy claramente Bachelard ${ }^{2}$ : «Se sueña antes de contemplar. Antes de ser un espectáculo consciente todo paisaje es una experiencia onírica. (...) Pero el paisaje onírico no es un cuadro que se llena de impresiones, es una materia que pulula.».

${ }^{1}$ Gaston Bachelard, L'eau et les rêves. Essai sur l'imagination de la matière (Paris: José Corti, 1960).

${ }^{2}$ Ibid., p. 6. 


\subsection{Sistema de análisis}

Para analizar, para desentrañar quizá este agua puilulante en la obra narrativa de Augusto Roa Bastos, se procederá por etapas, considerando cada uno de los niveles que se integran por proximidad hasta conseguir el mayor grado posible de significación. Primero se considera las formas del agua en sí mismas, en su estructura en tanto que símbolos absolutos. Se trata luego de determinar la función narrativa de estos símbolos señalando las relaciones que se establecen entre los personajes y las estructuras simbólicas del agua. Por fin, se esboza una proyección de estas estructuras y funciones al conjunto de la obra para mostrar de qué manera las formas del agua se constituyen en una de las mediaciones fundamentales del proceso narrativo global.

\section{LAS FORMAS DEL AGUA: ESTRUCTURA Y SÍMBOLO}

\subsection{Definición}

En un segundo grado de significación, por debajo de su apariencia inmediata, las formas del agua encierran un valor simbólico de alcance casi siempre universal. El símbolo opera entonces como calificativo integrado a la forma del agua y, por consiguiente, hace de ella una forma estática y unívoca. Estos símbolos son estructurales en la medida en que todos son solidarios unos de otros a partir de una referencia única que es el agua; cada uno depende de los demás, por complementariedad o por contraste, y sólo puede ser lo que es por su relación con los demás. Se hablará principalmente de tres formas del agua ligadas a tres símbolos: el agua viva y benéfica; el agua estancada y maléfica; el agua temporal neutra, pero que participa de las dos, pasaje y puente entre el bien y el mal, entre la vida y la muerte. O bien, retomando la terminología de Marie Bonaparte y de Gilbert Durand ${ }^{3}$ : Eros, Tánatos y Cronos, opuestos y complementarios en una indisoluble trilogía.

\subsection{Cronos o el agua temporal}

Cronos es el agua temporal, el fluir devorador en el que se inscribe la voluntad de poder. El agua temporal es el río que marca a la vez el

\footnotetext{
${ }^{3}$ Marie Bonaparte, Chronos, Eros, Thanatos (Paris: P. U.F., 1952); Gilbert Durand, Les structures anthropologiques de l'imaginaire (Paris: Bordas, 1969).
} 
destino nacional del Paraguay y los destinos individuales de los personajes.

A orillas del río Paraguay, Miguel Vera ${ }^{4}$ recuerda el Tebicuary, el río familiar de su infancia; esta evocación íntima viene contrastada por la contemplación objetiva del río nacional, del río histórico y colectivo: «Este es el hierático Río-de-las-Coronas, que los guaraníes endiosaron y acabó en bestia de carga, dando su nombre a la patria» (H. 170). Para el Supremo, el Río de las Coronas que fluye al pie de la Casa de Gobierno es el fundamento mismo de su poder estatal, como lo era para el antiguo Egipto «la gran serpiente del Nilo (que) repta a los pies de las pirámides» (S. 81). Para él, fundar y proteger el país es ante todo controlar los ríos y cerrarlos a la libre navegación de los imperialismos circundantes.

En El trueno entre las hojas o en Hijo de hombre, la guerra del Chaco opone dos paisajes a la vez que dos países: «el altiplano pétreo y desolado» y los «grandes ríos, grandes bosques paraguayos» (T. 82).

Miguel Vera, como buen oficial egresado de la Escuela Militar, sabe muy bien que el río es el elemento estratégico esencial: «La irrupción boliviana cierra sus dispositivos para cortar el río Paraguay, nuestro vulnerable espinazo de agua. Si llegan a tener su control, podrán doblar en dos al país y metérselo en el bolsillo» (H. 181).

En La gran solución, los civiles que se quedaron en Asunción son la presa de un pavor pánico ante la noticia del avance boliviano: «iSi ya están casi sobre el río! Indios de porquería» (T. 177). Y al alegre espectáculo de embarque de tropas hacia el frente sucede pronto el escepticismo inquieto y el desánimo: "Las charangas del muelle se habían vuelto lúgubres. (...) Pero ¿es que entonces esos tontos muchachos campesinos que se iban en los barcos no sabían pelear?» (T. 179).

Controlar el río es también el primer objetivo de las rebeliones militares, y desde la primera hora de las sublevaciones se ven las «cañoneras fondeadas en la bahía» (B. 32). Al teniente Godoy, el rebelde vencido de Regreso, lo fusilan en el Bajo de Asunción, frente al río patrio: «A lo lejos el agua de la bahía semejaba una chapa de cobre bruñido, levemente tornasolada» (T. 108). El río, agua temporal, es también el signo de los destinos individuales. Para el protagonista de Galopa en dos tiempos, regresar del exilio es volver a cruzar el río, «regresar al país desli-

${ }^{4}$ Las obras de Augusto Roa Bastos citadas en el texto, con sus abreviaturas correspondientes, son las siguientes: T. El trueno entre las hojas (Buenos Aires: Losada, 1968); H. Hijo de hombre (Buenos Aires: Losada, 1967); B. El baldio (Buenos Aires: Losada, 1966); M. Moriencia (Caracas: Monte Avila, 1969); S. Yo el Supremo (Buenos Aires: Siglo Veintiuno, 1974). 
zándose por el puente levadizo de una de las intermitentes amnistías» (T. 118). En cuanto a Lacú Godoy, de Regreso, «que se había alejado de su casa a los once años para descubrir el mundo» (T. 100), este descubrimiento del mundo cabe entero en una simple ida y vuelta sobre el río Paraguay.

\subsection{Eros o el agua viva}

Eros es el agua viva que tiñe de deseo el destino del hombre, deseo de inocencia y de amor. El agua viva, bajo su forma de río, arroyo o manantial, tiene un valor positivo. Su simbólica, ya se sabe, remite a la pureza, la luz, la alegría, la fertilidad.

En La rogativa, inocencia y pureza de la mansa locura de Felipe Tavy que se expresa en una risa de arroyo: «Una risa pura, casi olvidada. (...). Felipe Tavy sigue riendo con su risa limpia de arroyo. No tiene otra manera de expresar su extraña felicidad» (T. 174). Alegría y pureza de los niños en sus juegos acuáticos. Para Manuel Ramos, de El aserradero, el verde paraíso de la infancia queda asociado al agua viva, un tiempo feliz «como cuando éramos chicos y nos íbamos a nadar al arroyo» (B. 51). Juegos infantiles que el sigiloso Supremo observa desde su ventana:

Del otro lado del riacho Kará-Kará lavanderas baten ropa en la orilla. Muchachuelos se bañan desnudos. Uno de ellos mira hacia aquí. Levanta el brazo. Señala la Casa de Gobierno. Una de las mujeres, santiguándose, lo arroja al agua de un capirotazo. El negrito pega un chapuzón. (...) El negrito ha vuelto a reflotar arrojando buches de agua. Blande al aire los dientes blanquísimos. Bulla entre el parvilaje (S. 98 y 101).

E1 símbolo del agua viva está también ligado con las pulsiones del puro deseo erótico. En su feminidad, el agua viva nos refleja a veces la imagen, vagamente narcísica, de alguna cara de enamorada. Así la Petronila de $E l$ aserradero, que espera ansiosa de amor el regreso de su marido y se mira en el agua clara de la batea que le ha preparado para su limpieza: "Se ha mirado en el agua de la batea, y desde esa cara que está debajo del agua morada dos ojos juntos y ligeramente oblicuos la miran preocupados» (B. 55). O la Damiana Dávalos de Hijo de hombre, a la que evoca Miguel Vera como recuerdo de su infancia: «A veces, en el río, cuando iba a lavar la ropa, me hablaba (de su marido). (...) Su cuerpo joven quedaba inmóvil sobre el agua. Yo veía su sombra en la arena del fondo» (H. 69). 
Esta feminidad acuática, que se encarna repetidas veces en personajes de lavanderas, provoca en el niño sus primeras emociones eróticas. La atracción que siente el joven Miguel Vera por la Damiana Dávalos se origina en una imagen acuática en la que se superponen la madurez de Damiana y la pubertad de la Lágrima González, su compañera de infancia:

Igual que en el río, cuando su sombra caía sobre la arena del fondo. Le veía las rodillas y los muslos redondos. Yo estaba tendido cerca del río. (...) De pronto la Damiana Dávalos se transformó en la Lágrima González. Yo pegué un brinco. La Lágrima đejó de lavar, se sacó la ropa de un tirón y se echó al agua desnuda (H. 74).

En Cigarrillos «Máuser», el joven protagonista se inicia en los misterios del amor con la complicidad de la negra Petrona. Su primer encuentro es a orillas del río: "Venía a lavar la ropa algunos días a la semana. El chico la acompañaba a la playa» (T. 93); y la primera cita amorosa que le da Petrona es también a orillas del río: «Andate a pescar como siempre. En la otra curva del río. Hacia Paso Aguirre. Bajo el timbó grande. En el tacuaral» (T. 87 y 94). Y es también a orillas del agua donde el negro Pilar, el paje del Supremo, da rienda suelta a su libertinaje sensual:

También al negro le gustaba yogar con la india Olegaria en las medias islas del arroyo. Volaba feliz entre el olor de las fritangas, los chipás, las naranjas, el sudor, el hedor, los gritos de placer de las placeras. Les pellizcaba las nalgas, los senos. Metía la mano-trompetilla bajo las polleras de las más pollas, sólo para libar el ácido aroma a polen-hembra, sin el cual estamos otra vez en el Eclesiastés (S. 415).

Actividades todas éstas que el puritano y desencarnado Supremo sitúa muy por debajo de la línea de flotación de la Razón Universal: «de la línea del bajo vientre para abajo» (S. 414).

Otras formas del agua viva: el manantial y la lluvia, el frescor y el agua lustral. El agua clara para la sed que la chipera María Rosa ofrece a sus clientes o a Gaspar Mora, «el agua fresca del manantial del cerro» (H. 26), y el agua celeste que, como dice Macario, purifica de todo contagio leproso al Cristo tallado por Gaspar Mora y que el cura de Itapé se niega a recibir en su iglesia: "No está emponzoñado por el mal. La llivia lo lavó y purificó cuando lo traíamos» (H. 31).

Cuando Casiano y Natí, sucios de la pestilencia del estero y de los delirios de los yerbales, llegan por fin a la meta liberadora del río Mon- 
day, lo primero que hacen es sumergirse en las aguas vivas para limpiarse de todos estos males y recobrar su figura humana:

Hacia el anochecer llegaron al río. Se arrojaron de bruces en la orilla, bebiendo largamente como bestias. (...) El agua disolvió la costra de barro. Los rostros cadavéricos se fueron humanizando. Natí bañó a su hijo en el mismo lugar donde a ellos les habían prohibido que se bañaran (H. 113-114).

\subsection{Tánatos o el agua estancada}

Tánatos es el agua estancada, el fin último, la muerte y la disolución orgánica. El agua estancada bajo las formas de estero, karuguá, bañado, pantano o zanja, tiene un valor negativo y destructor. Su simbólica es la de la negrura, la impureza, la podredumbre, el misterio vertiginoso e insondable. Por oposición al agua viva, que simboliza las fuentes claras y vitales del bien, el agua estancada simboliza las fuerzas oscuras y mortales del mal.

El agua estancada, como imagen del mal, viene muchas veces ligada a otra figura simbólica de signo parecido: la serpiente, bajo sus diversas denominaciones locales. El protagonista de Audiencia privada evoca «la ñandurié que lo picara una vez en el bañado» (T. 77). El joven Pirulí «fue quien, buscando una vaca, encontró la enorme víbora a orillas del bañado» (T. 149). En Hijo de hombre, Casiano y Natí, huyendo por el bañado, se encuentran con un «mboí chiní»:

El irritado chasquido del crótalo les erizó la piel con la urticación del pavor. (...) Natí alzó en alto al crío instintivamente, para defenderlo de las mordeduras de la cascabel. Ya la veían saltar sobre ellos por el aire. Casiano procuró despegar los pies de la ventosa de barro. Resbaló y cayó desapareciendo por completo de la superficie. Por un instante, que a ella se le antojó interminable, Natí no vio de él más que una o dos burbujas que se rompieron en fofas explosiones. Avanzó unos pasos y manoteó en el agua gelatinosa, tratando de no mojar al crío, pero ya Casiano se incorporaba tambaleante, negro de barro, arrojando barro negro por la nariz y la boca (H. 105).

Por fin, en la pesadilla de su duermevela, un personaje de $E l$ prisionero siente que el sueño, al que se resiste con todas sus fuerzas, «se anillaba en torno a él como una kuriyú viscosa, inexorable, que lo iba ahogando lentamente» (T. 196).

El bañado viene siempre representado como una trampa alucinante 
y mortal. Fangosa pesadilla de Casiano y Natí, atrapados en el pantano y que conocen...

Esa rara sensación de que la tierra era la que caminaba bajo el agua, girando gomosa sobre sí misma sin ir hacia ninguna parte (...).

Se internaron en un bañado crecido por el chaparrón de la noche. Las aguas fermentaban bajo las veteaduras rojizas que habían dejado los raudales.

Los dos fugitivos avanzaron en dirección a una franja de monte, hundiéndose hasta las rodillas en el barro, sofocados por las miasmas, sin intentar defenderse siquiera de las picaduras de los insectos que flotaban en miríadas entre el vapor escarlata de las emanaciones (H. 104).

El paisaje del agua estancada, tal como aparece en el cuento El karuguá, en el que constituye el elemento principal, es también el lugar de todos los maleficios: «Monstruosos torbellinos vegetales de helechos y macizos espinosos que se adensaban en la gelatina negra de barro, como en otra edad geológica: un reino caótico y vibrante de alimañas voraces, de víboras y pájaros de presa» (T. 127). En este cuento, el karuguá viene representado como «un vasto tembladeral» (131), "pantanos de lodo negro y hediendo (...) tumba semilíquida de betún» (134), «caldo negro y brillante (...) vapores nauseabundos» (142). E1 hedor y la negrura señalan la capacidad infectiva del agua estancada. Capacidad epidémica que consigue contaminar hasta las nubes del cielo: «Pero si hasta las nubes son sucias, del color del algodón en rama entreverado de tierra; seguro porque se llevan las aguas del estero que rodea nuestra región» (B. 48).

El maleficio del agua estancada contamina también al hombre en lo más íntimo y vital de su ser: la sangre. Desesperación de los obreros de los yerbales del Alto Paraná, convencidos de la imposibilidad de evadirse de su presidio: «Esta certeza, esta leyenda, fermentada en la sangre, en la imaginación de los mensúes, como las miasmas palúdicas de un estero» (H. 80). O el fatalismo desesperanzado de los peregrinos de Borrador de un informe: "Y es así como también toda esta sangre estancada en la desidia y que va fermentando como las aguas de un pantano, les cría bajo el pellejo malos humores que luego revientan en hechos que ya no se pueden remediar» (B. 61).

Esta acción disolvente, física y moral, del estero, es la que evoca Macario cuando habla de la lucha tenaz del Karaí Guasú, el Supremo, contra sus opositores políticos: «Sus contrarios, vendidos a los mamelucos y porteños, conspiraban día y noche para destruirlo a él. Formaban 
el estero que se quería tragar a nuestra nación. Por eso él los perseguía. Tapaba con tierra el estero» (H. 15).

El narrador de El karuguá intenta penetrar el misterio que rodea la vida de Sergio Miscowsky, el patriarca del lugar. Su primera fuente de información es una gorda posadera cuyo relato le aparece muy pronto como un conjunto de maledicencias y de calumnias, impregnadas por las emanaciones del agua corrompida: «las miasmas del pantano salían por la boca de la mujer» (T. 129), "el tufo mefítico de la posadera» (132). $\mathrm{Y}$ en este proceso de identificación de la posadera con el karuguá, las miasmas simbólicas llegan a tomar en esta mujer la forma concreta de una sonora ventosidad intestinal, como una burbuja que reventara en la superficie del agua pútrida: «La posadera se lanzó un cuesco que sonó debajo de ella sofocado entre sus ropas. (...) El olor llenó la pieza, como si la fetidez del estero hubiera caído de pronto allí como un elemento más de la evocación» (137).

Por fin, si el agua viva evoca a los amores claros y juveniles, el agua estancada remite, al contrario, a los amores turbios y venales. Si la sombra del incesto se cierne un instante sobre el karuguá de Sergio Miscowsky, es, sin embargo, con la prostitución con lo que se relaciona sobre todo la imagen del agua impura.

El protagonista de Galopa en dos tiempos se dirige hacia el rancho de Rosa, a quien conoció en su juventud y quien se encuentra ahora en un estado extremo de degradación física y moral. El olor del jazmín, que evoca el agua celeste y los primeros amores, queda sumergido en las miasmas de la zanja que bordea el rancho:

Se detuvieron ante un rancho de mala muerte entre dos ranchos iguales diseminados al borde de una gran zanja cuyo hedor les llegó, a ella no, a él, con la emanación pútrida de aguas servidas estancadas. Contra el hedor del sumidero, el aroma de un jazmín de lluvia y de un níspero raquítico luchaban inútilmente como tábano contra una osamenta (T. 122).

Maleficio y fascinación de las aguas estancadas, siempre ligadas con la prostitución, es lo que experimenta el narrador de Borrador de un informe cuando se le entrega en su despacho la prostituta María Dominga:

Ante mi vacilación, entreabrió el manto y con un hábil meneo dejó caer a sus pies el liviano vestido y apareció ante mí completamente desnuda, inundando el despacho con su olor a mujer pública, a hediondez de pecado, a esos pantanos que en ciertas noches nos atraen con su sombria pero irresistible pestilencia (B. 74). 
Cronos, Eros, Tánatos son los símbolos y los valores de las formas del agua en el relato. Pero estas formas estructurales no se inscriben en el texto únicamente como símbolos y valores absolutos. Las formas del agua determinan también, en el discurso narrativo, la acción y el destino particular de los personajes.

\section{FunCión Y AMBIVALENCIA}

\subsection{Definición}

A nivel de su función en el relato, las formas del agua tienen un valor relativo que se distingue del valor absoluto que tienen a nivel del símbolo. Son relativizadas por su manera de conformarse con la actuación de los diversos personajes. Estudiar las formas del agua como símbolos es estudiarlas en su morfología; estudiarlas como funciones es estudiarlas en su sintaxis. Al valor estático de los símbolos se opone el valor dinámico de las funciones. Se pasa del valor en sí que es el símbolo al valor por sí que es la función, en la medida en que la función es considerada como la relación paradigmática entre dos elementos distintos pero interdependientes: las formas del agua representadas y los personajes en acción.

\subsection{Campos afines a las formas del agua}

Antes de hablar de la relación actancial de las formas del agua con los personajes conviene señalar algunos campos afines a estas formas, las demás formas líquidas que de alguna manera impregnan la sustancia misma de la escritura por medio de la representación, la imagen, la metáfora, la connotación acuáticas.

Primero, en lo lexical, se podría hacer un recuento de las imágenes secundarias del agua que pondría de manifiesto en la escritura de Augusto Roa Bastos la gran frecuencia y recurrencia de palabras como «flotar», «ondear», «ahogar», «inundar», «tembladeral», «barro», «sumergir», «estancado», "náufrago», etc., utilizadas casi siempre en sentido figurado, pero que constituyen, en un segundo grado, los indicios significativos de la acción de los personajes. Valgan dos ejemplos puntuales entre los muchos que se podrían encontrar en los textos. Macario, historiador de una época abolida, es evocado en estos términos: «El fluctuaba estancado en el pasado» (H. 15). La fuerza de la manifestación masiva de mu- 
jeres en $L a$ rebelión es sugerida a partir de un campo lexical que remite al movimiento del agua y a la navegación:

Lo primero que se adivina en el gentío es que su actitud, si bien puede confundirse con un aire de fervor religioso, no tiene nada de esa pasividad por delegación en que las procesiones parecen anclar. Este gentío está encallado en un tozudo empecinamiento, en una especie de irrevocable confianza en las propias, limitadas, débiles fuerzas. Un oleaje que al batir la escollera se hubiese petrificado en su propia fragilidad. Si se pudiera oírlo desde aquí, se diría que el rumor sube y se apaga por momentos en algo distinto a un bisbiseo de plegaria, como si la multitud deliberara en voz baja, como si el oleaje, a pesar de su cristalizada inmovilidad, continuara batiendo la escollera invisible (B. 37-38).

Otro campo afín sería el de las bebidas. El agua, por supuesto, pero también el alcohol, la leche, la cerveza, el mate, el café. Más directamente todavía, se podría hablar de las formas líquidas que emanan de los propios personajes, tales como las consideran Bachelard y Gilbert Durand, y que por su frecuente representación merecen ser señaladas: la saliva, el sudor, la sangre, los orines, las lágrimas... Las lágrimas, por ejemplo, que vierten los ojos ciegos de Solano Rojas, y que tienen la pureza matutina del rocío: "Y cuando entre los fuegos el ojo de su corazón la veía pasar a ella, una extraña exaltación lo poseía. Dejaba de tocar y los ojos sin vida echaban su rocío. En cada gota se apagaban paisajes y brillaba el recuerdo con el color del fuego» (T. 248).

Todos estos campos, sin embargo, nos alejan del agua natural y referencial como objeto del presente estudio. De ahí esta limitación voluntaria a considerar únicamente las relaciones inmediatas de los personajes con las formas del agua convencionales.

\subsection{Los destinos acuáticos}

En las relaciones actanciales de los personajes con las formas del agua se tratará sobre todo de dos funciones esenciales, una de vida y otra de muerte, que señalan los destinos acuáticos de los personajes.

Primero están los personajes que sin su relación simbiótica con el agua no serían lo que son, perderían su atributo fundamental: los navegantes, los paseros, las lavanderas que pueblan los relatos de Augusto Roa Bastos. Y más precisamente los ejemplares carpincheros, los «gitanos del agua», personajes acuáticos por antonomasia; Solano Rojas, el pasero ciego, patriarca del Tebicuary; los anónimos e innumerables «marineros», 
«remeros», «balseros», «lavanderas», «carpinteros de ribera», todos los obreros del agua que integran la «gente-muchedumbre» sobre la cual el Supremo fundamenta su poder absoluto.

Pero están sobre todo los personajes para quienes el agua marca el final de un destino y de una vida. Las muertes por el agua abundan en los relatos. Son más de doce los personajes actantes identificados que mueren por ahogamiento. A los que hay que añadir los ahogados anónimos, víctimas de la represión y el suicidio colectivo de toda la población de Yvyrá-Kaïgué que se ahoga en El karuguá (T. 139). Y teniendo en cuenta también los anegamientos frustrados de Manuel Ramos (B. 53) y de Miguel Vera (H. 22-23). Y también el falso anegamiento de Mano Cruel en el Tebicuary (T. 64-65). Y también, por fin, los muertos de sed y los camioneros aguateros de Hijo de hombre que mueren por y para el agua.

Ahora bien: este destino acuático no tiene la misma significación o el mismo valor si se tiene en cuenta el carácter del personaje y la forma del agua en la que se inscribe su destino.

Por una parte están los personajes que participan de lo que Bachelard llama el «complejo de Ofelia». Son los personajes positivos, de inocencia y de pureza, que buscan o hallan su muerte en las aguas vivas del río o del arroyo, vagamente enturbiadas por estas muertes suicidas. Tal como la del narrador de Nonato, que ya no soporta la incomunicación con su madre:

Mañana me iré al puente a oír pasar el retumbo del tren, bien metido bajo el agua; voy a pegar como siempre mi cabeza al pilote, pero no voy a ponerme la cañita en la boca; me quedaré escuchando con los dientes apretados hasta que la dentera del ruido se me vaya apagando en los huesos con los otros ruidos que tamborean dentro de mí sin descanso (M. 24).

Tal como la del viejo maestro Cristaldo de Bajo el puente, quizá una misma muerte vista desde otra perspectiva, que en su final acuático recobra la inocencia de una cara de niño:

Tengo la misma edad del maestro cuando se desgració bajo el puente, esa mañana en que todos los alumnos fuimos en fila a ver su cara bajo el agua barrosa. (...) Lo que vimos desde el puente, entre el olor de las victorias-regias (...) era la cara arrugada de un chico. Menos que eso: la de un recién nacido (M. 36). 
Tal como la de Alba Ozuna de El pájaro mosca, mancillada por la soldadesca ( «Unos soldados del Batallón de Escolta violaron a Alba en los zanjones de la Chacarita», B. 151), pero que recuperará en el agua lustral la pureza de un destino que su padre evoca en una visión premonitoria: «Mi pobre Ofelia, que también un día se morirá ahogada» (B. 138). Tal como, por fin, la de Solano Rojas de El trueno entre las hojas:

Resbaló en la arena de la barranca y cayó al remanso donde guardaba su balsa, donde lavaba su ropa harapienta, de donde sacaba el agua para beber.

De allí lo sacaron los carpincheros, que estuvieron toda la noche sondando el agua con sus botadores y sus arpones, al resplandor de las hogueras.

Lo sacaron enredado a un raigón negro, los brazos negros del agua verde que lo tenían abrazado estrechamente y no lo querían soltar (T. 248).

Por otra parte están los personajes que participan de lo que el mismo Bachelard llama el «complejo de Caronte». Son los personajes negativos, turbios e impuros, que hallan o buscan su muerte en las aguas estancadas del estero o en las zanjas de aguas corrompidas. Tal como la de Hugo Saldívar de El prisionero, torturador y ejecutor de su propio hermano, al que, en la oscuridad de la noche, no ha reconocido: "Al día siguiente, los hombres de Peralta encontraron el cadáver de Hugo Saldívar flotando en las aguas fangosas del estero. Tenía el cabello completamente encanecido y de su rostro había huido toda expresión humana» (T. 198). Tal como la del protagonista de Galopa en dos tiempos, que pasa del cinismo al horror hasta dar fin a su proceso de autodestrucción, que culmina con la pérdida de la identidad: «Algunos días después, boyando en el espeso y nauseabundo caldo del zanjón, encontraron el cuerpo de un hombre. No lo pudieron identificar» (T. 125).

\subsection{Las ambivalencias}

A veces, la determinación de las formas del agua y de sus funciones pasa por el filo que separa el Eros y el Tánatos de un mismo personaje. En Hijo de hombre, Salu'í ejerce el más antiguo oficio del mundo a orillas del agua inmóvil: «Un tiempo antes, cuando se estaba formando el 'barrio' bajo, cerca de la laguna, supo agenciarse la choza de pindó y adobe. (...) Ella no tenía más que su impúdica popularidad, que iba creciendo en el ranchito a oscuras, a orillas del agua» (H. 213). Sin 
embargo, esta agua inmóvil de la laguna de Isla Po'í, intermedio entre el agua viva del arroyo y el agua estancada del estero, es también el agua salvadora para los soldados del Chaco. Salu'í, como la María Magdalena bíblica, se va a reunir con Cristóbal Jara y su camión aguatero: el agua de la laguna, teatro de su degradación, será también el camino de su regeneración: «En lo más hondo de su degradación habría sentido resucitar su virginidad como una glándula, renacer, purificarse, bajo ese sentimiento nuevo y arrollador» (H. 214). Una especie de retorno a los orígenes, tal como lo sueña también Miguel Vera, acosado por la sed y rodeado de cadáveres putrefactos:

Aquí fue creado el Primer Hombre. Cualesquiera de estos árboles pudieron ser el Arbol de la Vida y el Arbol del Bien y del Mal, y no sería difícil que en la laguna de Isla Pơí se hubieran bañado Adán y Eva, con los ojos deslumbrados aún por las maravillas del primer jardín. (...) Estas serían las cenizas del Edén, incinerado por el Castigo, sobre las cuales los hijos de Caín peregrinaban ahora trajeados de kaki y verdeolivo (H. 196).

Si las distintas formas del agua corresponden cada cual con un valor o un símbolo, no siempre, ni mucho menos, se presentan en un sistema de relaciones estrictamente maniqueas. Cada cual conserva, por cierto, su característica dominante, pero se producen entre ellas vaivenes e interferencias que matizan su valor simbólico absoluto. Algo así como lo que dice el narrador de Borrador de un informe: «Debe ser porque en la vida todo anda mezclado: lo bueno y lo que es un poco sucio; lo santo y lo que es un poco del diablo» (B. 62). O, bajo una formulación más conceptual y heracliteana, la misma idea que expresa el Supremo aludiendo al agua viva: «Esta agua que pasa es eterna porque es fugaz. La veo, la toco, precisamente porque pasa y se repone en el mismo instante. Vida y muerte forman el pulso de su materia, que no es figura únicamente» (S. 297). La misma idea también, expresada por el narrador de El kuruguá, pero aplicada ahora a las aguas estancadas: «Allí reinaba implacable la humedad destructora y creadora, transformando continuamente la muerte en vida y la vida en muerte» (T. 127).

Para Bachelard, esta capacidad de restituir la ambivalencia del agua elemental, que llama a veces «aguas compuestas», es la virtud fundamental de la imaginación material ${ }^{5}$ :

Una materia que la imaginación no puede hacer vivir doblemente no puede cumplir la función psicológica de materia original. Una ma-

\footnotetext{
${ }^{5}$ Gaston Bachelard, op. cit, pp. 16-17.
} 
teria que no da lugar a una ambivalencia psicológica no puede encontrar su doble poético que permite las transposiciones sin fin. Es necesario entonces que se dé la doble participación —participación del deseo y del temor, participación del bien y del mal, tranquila participación del blanco y del negro - para que el elemento material cautive el alma entera.

Y es así como el agua estancada puede ser a la vez muerte y vida, pureza e impureza. En El karuguá, la figura pura e ideal de Isabel Miscowsky nace de la misma pestilencia del estero: «... de la que ella había surgido y era su viviente vestigio, una flor inmaculada sobre el vasto tembladeral que la rodeaba como un templo, pero también como una tumba» (T. 131). El estero, que es muerte y desolación, puede ser también proveedor de alimento. E1 técnico Sergio Miscowsky introduce en el maléfico karuguá el cultivo del arroz, creando una fuente de vida en el mismo lugar de la muerte. Lo mismo ocurre con los arrozales que don Francisco Morel cultiva en el estero de La tumba viva. Y lo mismo ocurre también con el ingeniero y el ministro de Audiencia privada, para quien desecar y canalizar los esteros del Tebicuary: «Es un proyecto muy importante. Esa obra puede ser la salvación de los pobladores que viven en esos bañados insalubres aporreados por el paludismo, por las crecientes, por las sabandijas» (T. 71).

El agua viva del río o del arroyo es también portadora de vida y de muerte mezcladas. Como cuando al final de su huida, al salir de la pesadilla mortal de los yerbales y del estero, Casiano y Natí recuperan, a orillas del río Monday, sus primeros momentos de calma y de humanidad:

Se arrojaron de bruces en la orilla, bebiendo largamente como bestias. (...) Estaban en una depresión de la barranca, pero ella se manejaba ya como en la cocina de su rancho. Tomó el machete y se internó en el agua hasta llegar a unas plantas de maíz de agua. Comieron los bulbos de las victorias-regias (H. 113-114).

Para Margaret Plexnies, de Carpincheros, el agua viva del río es a la vez la muerte de su existencia familiar y la cuna de donde va a nacer a la vida mítica que eligió; y es en el río donde el Supremo, que afirma no haber nacido de hombre ni de mujer, va a buscar sus orígenes primeros; y es también en el agua donde el narrador de Nonato, que siente la separación de su madre como una mutilación, recobra la paz fetal y la comunicación umbilical con el mundo y con la vida: «A todo lo más que llego es hasta el puente a oír pasar el retumbo del tren, la cabeza 
bajo el agua, respirando por una cañita, abrazado al pilote, para sentir en los dientes el tiritar del ruido. O voy a encerrame en el socavón del barranco con el tambor» (M. 19). Vida y muerte relacionadas con el agua en Moriencia, donde el ataúd de Chepé Bolívar se parece a una canoa y la canoa del maestro Cristaldo a un ataúd:

Lo veíamos al uno reflejado en el otro, como formando una sola persona. Uña y carne. Flaquito, inacabado, muy blanco, el uno. Alto el otro, desgalichado, muy oscuro. Cuando Chepé ya no se pudo mover, el maestro iba a su casa a darle una mano en el trabajo. Hacía mucho tiempo que la caja estaba terminada, pero entre los dos siempre encontraban algún detalle que retocar o afinar. Parecida a una canoa, la caja; a la canoa del maestro Cristaldo. Tal vez mejor; de más calidad, más resistente, mejor perfilada. De primera para remontar el río hasta sus nacientes, como quería el maestro, que únicamente podía bogar en la laguna; su viejo cachiveo hacía agua por todas partes (M. 12-13).

El río es también una tumba que recibe los cuerpos supliciados de los obreros y de los guerrilleros. Esteban Blanco es el primer obrero insurgente de El trueno entre las hojas: "Fue el primer rebelde y el primer muerto. Lo arrojaron al río. El cadáver se alejó flotando en un leve lienzo de sangre sobre la tela verde y sinuosa del agua» (T. 225). Y este destino va a ser el de muchos otros más: José del Rosario, Tanimbú, Anacleto Pakurí, Loreto Almirón...: «El río era una buena tumba, verde, circulante, sosegada. Recibía a sus hijos muertos y los llevaba sin protestas en sus brazos de agua que los había mecido al nacer. Poco después trajo pirañas para que no se pudrieran en largas e inútiles navegaciones» (T. 258).

Lo mismo ocurre con los que caen en la insurrección armada. En Regreso: «Por esos días el río bajaba lleno de cadáveres aureolados por cardúmenes de pirañas» (T. 106). En Encuentro con el traidor: «El coronel había hecho torturar y asesinar al estudiantito aquel, al que luego tuvieron que arrojar al río atado con alambre y fondeado con piedras de Tacumbú» (B. 26). En Hermanos, donde se evoca la suerte que les espera a los rebeldes capturados: «Seguro que los van a volver a tirar al río después de cuerearlos delante de la población civil... Estos también nacieron para bagres de correntada» (B. 102-103). Estos últimos ejemplos revelan una doble función del agua viva: como agua mortuoria y como agua regeneradora. El agua viva devuelve los cuerpos de los supliciados a sus orígenes en una especie de ciclo vital inagotable,

En su función de ambivalencia el agua puede ser libertad y prisión 
a la vez. Libertad para Lacú Godoy, de Regreso, que se escapa a nado de un barco brasileño; libertad también, o esperanza de libertad, para el protagonista de La excavación, que cava ansiosamente en el piso de su celda para llegar hasta el río. Lo anima la «creciente humedad» que encuentra en su progresión:

La barranca ya no estaría lejos; a lo sumo, unos cuatro o cinco metros, lo que representaba unos veinticinco días de trabajo hasta el boquete liberador sobre el río (...).

Por alli venía el olor puro de la libertad, un soplo fresco y brillante entre los excrementos (...).

Quizá no eran cinco metros los que faltaban; quizá no eran veinticinco días de zapa los que aún lo separaban del boquete salvador en la barranca del río (T. 79-81).

Y el agua es también una prisión. Prisión, en Regreso, para los cautivos del barco «Manduvirá», que se mueren de sed en medio del agua (T. 104). Prisión para los mensúes de los yerbales de Takurú-Pukú en Hijo de hombre, en medio de una naturaleza convertida en presidio y en donde casi todas las formas del agua se confabulan contra la libertad de los hombres:

Takurú-Pukú era, pues, la ciudadela de un país imaginario, amurallado por las grandes selvas del Alto Paraná, por el cinturón de esteros que formaban las crecientes, infestados de víboras y fieras, por las altas barrancas de asperón, por el río ancho y turbionado, por los repentinos diluvios que inundan en un momento el bosque y los bañados con torrenteras rojas como sangre (H. 81).

Prisión también para Miguel Vera, «destinado» en Peña Hermosa, un islote del río Paraguay: «Estamos fondeados en medio de la lenta y atigrada corriente, de más de un kilómetro de anchura, que ahora, por la bajante, hiede a limo recalentado por el sol» (H. 168). Puede nadar en el río hasta el cansancio bajo la vigilancia del puesto de centinela, pero este río-cárcel le recuerda otro río, el Tebicuary de su infancia, río de amor y de libertad:

Como cuando de chico me tumbaba cabeza abajo en las barrancas del Tebicuary para ver chispear el río del revés, erizado por el viento norte.

Pero éste no es el río de mi infancia, rápido, sinuoso, familiar, con su playa que a esta hora solía estar llena ya de lavanderas, de carretas atravesando el vado, de animales bebiendo, de gritos, de voces... (H. 170). 
Prisión refinada y sádica imaginada por el Supremo para castigo de los culpables:

El castigo que mejor define la esencia justiciera del régimen penal de este país: La condena a remo perpetuo. (...) No se envía al culpable a la muerte. Simplemente se lo aparta de la vida. (...) Nada tiene de opuesto a la naturaleza; lo que hace es devolverlo a ella. (...) Se lo mete engrillado en una canoa en la que se ponen víveres para un mes. (...) Se le da la orden de alejarse, de no volver a pisar jamás tierra firme. (...) El culpable irá bogando de orilla a orilla remontando o bajando el ancho río de la Patria, librado a su entera voluntadlibertad (S. 131-132).

Ambivalencia del agua viva purificadora que a veces funciona de una manera ilusoria e irónica, y también trágica. Es así como el agua viva sirve para sustituir los medicamentos que, por ser costosos, el patrón Simón Bonaví les niega a sus obreros enfermos en El trueno entre las hojas: «Ah, los pobres no tenemos derecho a enfermarnos. Ahí está el río. Denles agua, mucha agua, hasta que se cansen. El agua es un santo remedio» (T. 226).

De las enfermedades relacionadas con las formas del agua y representadas en el texto, la más terrible es la lepra. Y es allí donde mejor se nota quizá la ambivalencia del agua. El agua es el elemento primordial de supervivencia para los leprosos, sin el cual están condenados a una muerte rápida. Cuando el «Doctor» de Sapukai los abandona, los leprosos acuden al único amparo que les queda, el arroyo: «En torno al tabuco abandonado se agitan los fantasmas muermosos que van a beber al arroyo» (H. 60).

Pero esta agua purificadora para los leprosos se convierte en elemento contagioso para los demás, en barrera infranqueable para el ejército de represión que opera contra los montoneros de Sapukai. Y esto a pesar de que en el centro de este miedo al contagio surja la atracción del Eros, siempre relacionado con el agua viva y que en este caso toma la forma de la leprosa Iris:

¡No podemos ni bañarnos en el arroyo por culpa de los lázaros! (...) Dicen que entre los leprosos hay una maestra de Karapeguá, la hija del francés. Parece que todavía es muy linda. Algunos la vieron allá en los ranchos, cuando bajaban hacia el arroyo (...).

Continuaban mirando, no obstante, hacia los ranchos - especialmente las clases y soldados, con obsesiva fijeza-, acaso porque esperaban ver de nuevo a esa mujer de rubia cabellera que desde lejos parecía estar aún en el esplendor de la juventud y la belleza. 
La habían entrevisto una sola vez, yéndose al arroyo, en el atardecer de uno de los primeros días. Desapareció en seguida por el caminito que entraba en el monte. Los números exploraron sigilosamente los alrededores. Sólo vieron a los enfermos bañándose o lavándose las llagas (H. 144 y 155).

El agua viva, último consuelo de los leprosos, se niega a veces trágicamente, por su ausencia o su lejanía, a aliviarlos, provocando implacablemente su muerte. Es lo que ocurre con el leproso Gaspar Mora, a quien los suyos, preocupados por el cometa y la sequía, han olvidado por un tiempo:

Nos olvidamos de Gaspar Mora, solo en el monte. (...) María Rosa trató de llegar al abra con su pequeña carga de agua y provisiones. Pero no pudo.

Cuando el miedo aflojó, Macario y otros llegaron a la entrada del pique. (...) Empezaron a llamarlo a gritos. La oquedad del monte sólo devolvía ecos pastosos. Lo rastrearon hacia el arroyo. Allí lo encontraron, de bruces sobre los guijarros y la arena del cauce seco (H. 27).

Y el leproso mutilado y lastimoso de La tumba viva muere sin haber podido alcanzar el agua salvadora: «La caquexia, la sed lo fulminaron en el trayecto al arroyo hacia el cual avanzó arrastrándose. Sus labios, tumefactos por la lepra, no alcanzaron a mojarse en el agua cristalina, que sólo le sirvió de espejo final» (T. 213).

\section{Simbólica, poÉtica y pRagmática de un tema}

\subsection{Proyección en la obra}

La tipología de las formas del agua en tanto que símbolos y funciones se fundamenta sobre elementos textuales fragmentados, puntuales y dispersos en toda la obra; todos y cada uno sirven de apoyatura a la constante representación del agua. Estas formas del agua, por su acumulación, recurrencia y ambivalencia, convergen en un incesante proceso dialéctico para constituirse en una unidad temática que sostiene sincrónicamente el proceso narrativo del conjunto de la obra de Augusto Roa Bastos.

Ahora bien: esta temática se puede considerar asimismo desde una 
perspectiva diacrónica, tal como la ha definido, por ejemplo, David Maldavsky ${ }^{6}$ :

El hecho que se repita el conjunto de valores contrapuestos de ninguna manera indica una pérdida o un estancamiento desde el punto de vista estético. (...) Parecería como si Augusto Roa Bastos hubiese encontrado una nueva forma de seleccionar y combinar signos, en la cual se encuentran incluidos, reelaborados, sus anteriores sistemas estilísticos (...).

Existe una evolución con un progresivo enriquecimiento estético en la narrativa del autor consistente en la creciente articulación y densificación de los niveles hasta entonces no totalmente coherentes: sintáctico, semántico y pragmático. (...) Roa Bastos ha logrado una mayor complejidad y coherencia en cuanto a las estructuras profundas de su mensaje, cuya evidencia se revela en el nivel de la articulación de los signos de su producción narrativa.

Quedaría entonces por ver, en lo que concierne a este estudio, cómo viene desarrollándose y transformándose la temática del agua en los tres momentos claves de la obra de Augusto Roa Bastos que son El trueno entre las hojas (1953), Hijo de hombre (1960) y Yo el Supremo (1974); ver cómo el símbolo trascendente, más o menos bucólico (El trueno), se integra consustancialmente a una parábola épico-mística (Hijo de hombre) hasta trivializarse en una pragmática histórica (Yo el Supremo). En otras palabras: cómo se pasa de un agua dominadora a un agua dominada.

\subsection{Adaptación al simbolo}

En El trueno entre las hojas y en algunos cuentos posteriores, el agua y el río, en sus formas simbólicas más definidas, actúan como punto de referencia de la acción de los personajes. Estos conviven con las formas del agua y su acción se adapta a los valores inscritos en los símbolos que gravitan sobre sus destinos y los marcan definitivamente. Este paralelismo entre dos sistemas de valores autónomos, pero de signo complementario (los valores propiamente humanos y los del simbolismo acuático), es lo que explica, por ejemplo, la epifanía final de un personaje como Solano Rojas en su relación con el río. Para él, el río es el cuadro armonioso de un equilibrio recuperado:

' David Maldavsky, Un enfoque semiótico de la narrativa de Roa Bastos: "Hijo de hombre», en Helmy F. Giacoman (ed.), Homenaje a Augusto Roa Bastos (New York-Madrid: Anaya-Las Américas P. C., 1973). 
El círculo se había cerrado y volvía a empezar. (...) Se sentía a gusto en la barranca frente a las ruinas de la Ogaguasú. Era el sitio del combate, el sitio de su amor. Necesitaba estar allí, al borde del camino de agua que era el camino de ella (...).

Allí está él en el cruce del río, como un guardián ciego e invisible a quien no es posible engañar porque lo ve todo.

Monta guardia y espera. Y nada hay tan poderoso e invencible como cuando alguien, desde la muerte, monta guardia y espera (T. 247-248).

Esta actitud de serena pasividad frente al agua hospitalaria se mantiene de alguna manera en Hijo de hombre, ilustrando el destino de MacarioMiguel Vera, pero se transforma por completo cuando se toma en cuenta el destino de Cristóbal Jara.

\subsection{Integración de la función}

En Hijo de hombre, el agua deja de ser un elemento mayormente decorativo y referencial para convertirse en uno de los objetos mismos de la dramatización narrativa. Al quebrarse sensiblemente el paralelismo entre los valores humanos y los valores simbólicos del agua, se pasa de una simbólica general a una poética integrada. Si por una parte los valores simbólicos del agua se mantienen y se agrandan hasta la dimensión religiosa cristiana y mítica, por otra parte estos valores son activados y encarnados por la acción de ciertos personajes. Pasan de la trascendencia a la inmanencia. Ya no son una referencia a la distancia, sino la sustancia misma de una práctica: la de la lucha contra la injusticia, la de la solidaridad de los oprimidos. $\mathrm{Y}$ en este campo, el logos ideal de los símbolos absolutos pierde su pertinencia. Es de alguna manera lo que señala el taciturno Cristóbal Jara cuando dice: «Lo que no puede hacer el hombre, nadie más puede hacer. (...) No entiendo lo que se dice con palabras. Sólo entiendo lo que soy capaz de hacer» (H. 245). Para este personaje, que se sacrifica para llevar el agua salvadora a sus maltrechos compañeros del Chaco, «hacer» es:

Ir abriéndose paso en la inexorable maraña de hechos, dejando carne en ella, pero transformándola también con el elemento de esa voluntad cuya fuerza crecía precisamente al integrarse en ellos (...).

Uno caía, otro seguía adelante, dejando un surco, una huella, un rastro de sangre, sobre la vieja costra, pero entonces la feroz y elemental virginidad quedaba fecundada (H. 247). 


\subsection{Trivialización del signo}

La integración voluntariosa de la simbología acústica al quehacer humano que señala Hijo de hombre se produce mucho más llana y directamente en Yo el Supremo. El signo acuático se trivializa. El agua y el río configuran ahora una de las tantas referencias en las que se inscribe el ejercicio del poder absoluto y la ideología que lo sustenta.

Por cierto, las formas del agua conservan de alguna manera sus valores intrínsecos. También para el Supremo el río es el lugar del nacimiento y el lugar de la muerte. Sin embargo, la tipología establecida sufre, en este y en otros casos, distorsiones, subversiones y hasta inversiones. El nacimiento del Supremo se produce en un río en que se empañan las límpidas características del Eros que se han señalado. Ya no se trata del agua arrulladora, sino del espeso magma genético:

Me dirijo al río bajante; así tal vez me escuche. (...) Tú que nunca paras; tú que siempre pares; tú que no tienes antigüedad; tú que estás impregnado de la consciencia de la tierra; tú que has dado desde hace milenios tu humor a una raza, ipuedes ayudarme a desahogar mis almas múltiples aún en embrión, a encontrar mi doble cuerpo ahogado en tus aguas? Si lo puedes hacer, isí lo puedes!, hazme un signo, una señal, un hecho por pequeño e imperceptible que sea (304).

Me arrojé yo al agua. (...) Cerré los ojos y sentí que nacía. Metido en el cesto del Maíz-del-agua, sentí que nacía del agua barrosa, del limo maloliente. Salía al hedor del mundo. Despertaba a la fetidez del universo. Pimpollo de seda negra flotando en la balsa-corona, armado de un fusil humeante, emergiendo al alba de un tiempo distinto. ¿Nacía? Nacía (308-309).

La muerte también se relaciona con el río. Una de las hipótesis sobre el destino de los restos del Supremo es que éstos han sido arrojados al río; estamos otra vez en el río-tumba de la tipología. Pero cuando el mismo Supremo se representa su propio cadáver flotando sobre el agua, el río deja de ser una tumba para convertirse en una extensión más del espacio donde opera la voluntad de total dominación:

Empujado por el palo me siento boyar en las aguas estigialesvestigiales, mas también en otro río vivo, deslumbrante; el Río-de-lasCoronas, el Río-Río. Mi cuerpo se va hinchando, creciendo, agigantándose en el agua racial que los enemigos

iSiempre, hasta el final, la torturante y perenne obsesión del rio camino libre! (Julio César, op. cit.)

han creído atrancar con cadenas. Mi cadáver las va rompiendo una a una, dragando las profundidades, ensanchando las orillas (448). 
Este poder de ultratumba que ejerce el Supremo sobre el río es el mismo que el que practicaba en su vida histórica. Dominar el río, constituirlo en defensa natural, controlar la navegación, forman parte de las modalidades espaciales de su poder absoluto ${ }^{7}$. Este poder de todos los instantes y de todos los lugares viene representado plásticamente cuando en el relato se alude por dos veces al desvío, a pura fuerza de brazos, del río Pirapó (S. 34, en nota, y 192).

A la inversa, el agua puede ser también el lugar del deterioro de este poder absoluto. Pero esta inversión va mucho más allá de la simple ambivalencia. Cuando al Supremo no le queda más espacio que el de la escritura donde ejercer este poder, el agua se convierte en enigma y en agente sustentador-destructor. En enigma, cuando el espacio y materia de la escritura aparecen bajo una forma inédita de agua, la de la palangana en la que el amanuense Patiño baña sus pies:

El mismo se trajo la palangana de agua fría. Durante más de un cuarto de siglo tuvo metidos los pies en esa agua negra que se volvió más espesa que la tinta. Sin saberlo, sin proponérselo, logró contradecir a Heráclito. Los pies anfibios del amanuense se bañaron en la misma agua inmóvil en un siempre bastante parecido a la eternidad. (...) Al agua del río y hasta al agua de lluvia les tengo mucho miedo. A la una porque corre. A la otra porque cae igual que la cola llovida hacia abajo de la vaca o del caballo (...).

Por la noche me arrodillaba ante la palangana del amanuense. Al cono blanco de la vela, me inclinaba sobre el redondo espejo negro. Juntaba las manos y quedaba a la espera en actitud de orar. En algún momento, a las cansadas, algunas veces, no siempre, veía deslizarse muy lentamente borrosas imágenes parecidas a nubes, de un horizonte a otro sobre la superficie de betún. ¿Pensaban, pues, los pies del fiel de fechos al revés de su mente memoriosa e ignara? Alguna cosa secreta pensaban esas plantas anfibias... (S. 441-442).

Opacidad del agua escriptural, como la del karuguá «tumba semilíquida de betún», pero inmóvil, silenciosa, congelada. En los últimos estertores de su aniquilamiento final, el Supremo se aferra a esta impenetrable imagen acuática de la escritura, de la escritura-esfinge que lo fascina. Ya casi totalmente absorbido por ella, sólo le queda una mano autónoma que sigue escribiendo desesperadamente para alcanzar la supervivencia

${ }^{7}$ Jean Andreu, Modalidades del relato en "Yo el Supremo» de Augusto Roa Bastos: lo Dicho, el Dictado y el Diktat, en Seminario sobre "Yo el Supremo" (Poitiers, Francia: Centre de Recherches Latino-Américaines de l'Université de Poitiers, 1976), pp. 61-113. 
en la ficción de la letra rasgueada: «Ultima ratio, última rata escapada del naufragio. (...) La mano-rata-náufraga escribe...» (S. 450).

La última visión del Supremo es la esperanza o la certeza de que su aniquilamiento no será definitivo mientras quede, más allá de la historia y de la escritura, un átomo de su ser, de su pensamiento, capaz de resistir la acción disolvente del agua: «La sal de mi cuerpo empapado resiste intacta la viscosidad del Tercer Diluvio» (S. 452).

A modo de conclusión sobre esta trayectoria de una temática, cabe señalar que una de las primeras novelas de Augusto Roa Bastos, escrita por los años cincuenta y que permanece inédita, se intitulaba Las aguas vivas. Y si recordamos que una de las colecciones de textos del autor lleva por título Los pies sobre el agua, no resulta muy arriesgado afirmar, como se ha tratado de demostrar en este estudio, que el agua constituye en la obra de Augusto Roa Bastos una de sus firmes constantes textuales, pasadas y quizá futuras, por más que una de estas formas del agua señale en Yo el Supremo el naufragio de la escritura.

Université de Toulouse,

JEAN ANDREU

Le Mirail, France. 
